\title{
Analisis Pengaruh Variabel Makroekonomi Terhadap IHSG Setelah Terjadinya Krisis Subprime Mortgage
}

\author{
Riski Dian Rahmawati ${ }^{*}$, Dinar Melani Hutajulu' ${ }^{2}$, Yenny Aulia Rachman ${ }^{3}$ \\ ${ }^{1,2}$ UniversitasTidar, ${ }^{3}$ STAINU Temanggung

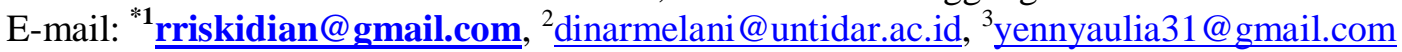

\begin{abstract}
Abstrak
Indonseia kembali terjadi krisis moneter pada tahun 2008 yang disebabkan oleh adanya Krisis Subprime Mortgage AS. Dan berimbas pada perekonomian Indonesia, sehingga tahun 2009 merupakan tahun awal pemulihan perekonomian dalam negeri.Tujuan penelitian ini, untuk mengetahui pengaruh'yang siignifikan dalam jangka panjang diantara variabel inflasi, Kurs dan BI Ratebagi IHSGsetelah terjadinya krisis subrime mortgageyaitu pada periode 2009 hingga 2019 dalm deret waktu triwulan. Penelitian ini termasuk jenis penelitian kuantitatif, dengan sampel 44 tiap variabel dan menggunakan metode ECM. Dari pengujian, menghasilkan hasil pada variabel Inflasi tidak berpengaruh bagi Indeks Harga Saham Gabungan baik jangka pendek $(0.7372>0,05)$ bertanda positif bernilai(0.0117) ataupun jangka Panjang (0.1650> $0,05)$ bertanda positif bernilai(0.177274), artinya arah sejalan bagi pergerakan Indeks Harga Saham Gabungan. Varabel Kurs berpengaruh bagi Indeks Harga Saham Gabungan baik jangka pendek $(0.0012<0,05)$ bertanda negatif bernilai(-0.7898) artinya arah kurs berlawanan, ataupun jangka Panjang $(0.0000<0,05)$ bertanda positif bernilai(1.055191), artinya arah sejalan bagi pergerakan Indeks Harga Saham Gabungan. Varabel BI rate tidak memiliki pengaruh bagi Indeks Harga Saham Gabungan baik jangka pendek (0.1924>0,05) bertanda negatif bernilai(-0.1577) artinya arah kurs berlawanan, ataupun jangka Panjang $(0.0025<$ 0,05) bertanda positif bernilai(-0.821875), artinya arah kurs berlawanan bagi pergerakan Indeks Harga Saham Gabungan.
\end{abstract}

Kata Kunci-Inflasi, BI rate, kurs, IHSG

\begin{abstract}
In the 2008 Indonesia returned to the financial crisis driven by the US Subprime Mortgage Crisis. And this has impact on Indonesian economy, so that 2009 was a start of domestic economic recovery. The purpose of this study is to find out the long term significant influence over the inflation variables, the Exchange Rate and BI Rate for IHSG after Subrime Mortgage Crisis in the period during 2009 to 2019 on quarterly payment time. This research is a quantitative research type, with sample of 44 each variable and using ECM method. From the test, it showed that inflation variable has no effect for the Composite Stock Price Index neither at the short-term (0.7372> 0.05) has positive value (0.0117) nor at the Long-term (0.1650> 0.05) has positive value (0.177274), means linear direction for Composite Stock Price Index movement. The Exchange Rate variable was determined neither at short-term Composite Stock Price Index $(0.0012<0.05)$ has a negative value (-0.7898) means that the exchange rate has opposite direction, nor at the Long-term $(0.0000<0.05)$ has positive value(1.055191), means linear direction for Composite Stock Price Index movement. BI variable rate did not have an effect for Composite Stock Price Index neither at the short-term (0.1924>0.05) has negative value (-0.1577) means that the exchange rate has opposite direction, nor at the long-term $(0.0025<0.05)$ has positive value (-0.821875), means that the exchange rate has opposite direction for Composite Stock Price Index movement.
\end{abstract}

Keywords-Inflation, BI rate, Exchange rate, JCI 


\section{PENDAHULUAN}

Krisis subprime mortgage ditahun 2008 merupakan kejadian dimana kegagalan di dalam pembayaran kredit perumahan yang terjadi di Amerika Serikat [1]. Dampak yang timbul bagi perekonomian global dan untuk mengembalikan perekonomian kekondisi yang normal memerlukan waktu yang tidak sebentar. Negara Indonesia sendiri memiliki hubungan diplomatic yang sangat erat dengan negara Amerika Serikat yang dimulai pada tahun 1949. Sehingaa apa yang sedang terjadi terhadap dollar AS dan Amerika Serikat sebagai negaranya akan memberikan pengaruh terhadap negara Indonesia. Subprime mortgage terdefinisi merupakan sebuah kepemilikan rumah melalui paket kredit, dan diberikan pada debitur, namun sebelumnya sama sekali belum pernah melakukan kredit atau pernah tapi dengan histori kredit yang tidak baik [2]. Hal tersebut menjadi peluang pada pihak ketiga dalam memberikan pinjaman untuk transaksi subprime mortgage loan (pembelian rumah). Krisis ini kemudian menggelembung dan merusak sistem perbankan dan keuangan sehingga memicu dampak krisis yang begitu luas bagi perekonomian global [3], [4]. Pemicu krisis subprime mortgageyaitu adanya mekanisme kredit secara ekspansif menimbulkan kredit macet dan adanya suku bunga the fed yang tinggi mendorong lembaga keuangan rugi [5]. Krisis subprime mortgage memberikan dampak terhadap perekonomian Indonesia. Sehingga negara Indonesia menjadi krisis moneter. Tahun 2009, menjadi tantangan terbesar bagi perekonomian Indonesia setelah terjadinya krisis subprime mortgage.

Selain itu krisis ini menyebabkan ketidakelancaran sistem keuangan dunia, yang berakibat pada menurunnya berbagai aktivitas ekonomi dan perdagangan internasional. Indonesia memiliki Pasar modal yang mana keadaannya dalam keadaan emerging market atau sedang berkembang, yang mana kondisi makroekonominya memiliki pengaruh yang sangat rentan dalam pergerakannya harga saham. Peran pasar modal sangat penting dan strategis untuk pertumbuhan perekonomian Indonesia. Adanya pasar modal, dapat mempercepat dan memiliki pengaruh jangka panjang dalam memberntuk modal dan akumulasinya.

Pasar modal, saat ini menjadi trick menarik pada kegiatan mendorong perekonomian negara, terdapat dua fungsi pada pasar modal yakni, sarana perusahaan dalam menambah modal dan sarana investor dalam kegiatan investasi [5]. Pada waktu jangka Panjang pasar modal menjadi trick yang efektif. Dalam transaksi ini, modal yang diperoleh sejalan dengan adanya resiko yang ada, dimaksudkan jika tingkat modal tinggi, diikuti resiko kerugian juga tinggi [6]. Artinya, investor sangat membutuhkan perkembangan harga IHSG pada saat akan berinvestasi. Dikarenakan IHSG menjadi bahan untuk mempertimbangkan di tahap awal sebelum berinvestasi [7]. Investor juga harus mempertimbangkannya dengan melirik faktor yang dapat menaikan atau menurunkan harga IHSG.

IHSG menunjukan penguatan dengan kenaikan 86 persen pada 2008. Pada tahun itu, IHSG mencapai harga tertinggi atau rekor yang tinggi. Namun pada pertengahan 2008, IHSG mengalami koreksi cukup berat dengan penurunan sebesar 50.64 persen dibandingkan tahun sebelumnya [8]. Sehingga pada tahun 2008 dinobatkan menjadi prestasi dan juga tahun keterpurukan bagi IHSG. Sedangkan untuk kurs mengalami penguatan di akhir tahun 2007. Kemudian pelemahan yang tajam terjadi di pertengahan tahun 2008. 


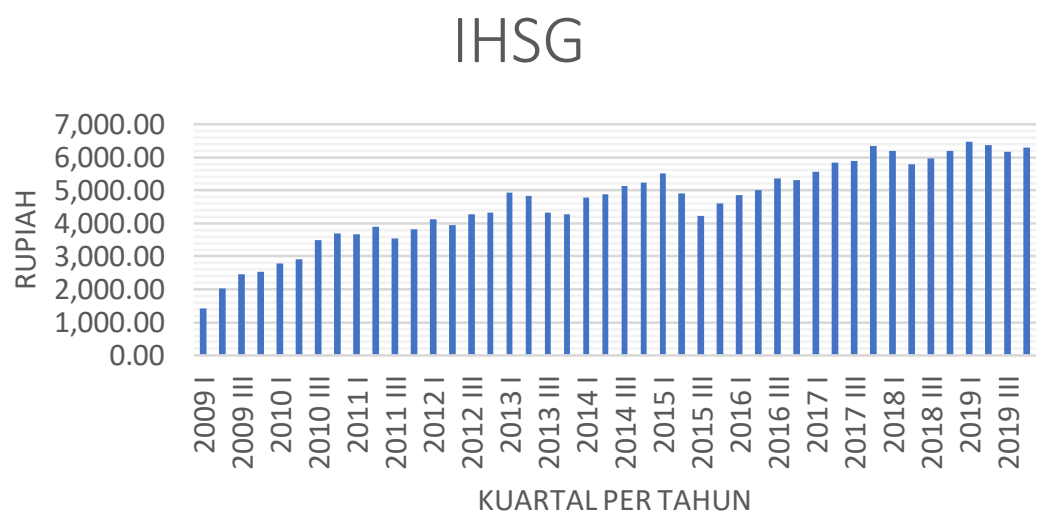

Gambar 1. Perkembangan IHSG periode 2009 - 2019 (Maret, Juni, September dan Desember) Sumber : bi.go.id

Gambar 1 menunjukkan bahwa pergerakan IHSG periode 2009 hingga 2019 menglami pergerakan yang fluktuatif. Dari gambar ditunjukan bahwa tahun 2011 IHSG menunjukan kinerja yang kurang memuaskan dibandingkan tahun sebelumnya karena terdapat sentiment negative dari eksternal dan menunjukan dalam area "barish" (pelemahan). Dari kalangan investor menilai, tertekannya IHSG kaena terpacu penggelembungan dana asing yang masuk pada tahun sebelumnya. Kondisi tersebut menyebabkan investor untuk mengamankan hartanya dengan melakukan penjualansaham yang dimilikinya.

Semester I tahun 2013, IHSG menunjukan penguatan yang cukup tinggi, yaitu dikarenakan adanya kenaikan saham properti. Kemudian mengalami dari gambar diatas terlihat bahwa IHSG mengalami penurunan secara bertahap hingga penutupan tahun 2013, penurunan ini disebabkan oleh adanya gejolak pasar finansial akibat rencana The Fed mengurangi stimulus fiskal dan melemahnya harga komoditas di pasar internasional. Selain itu penurunan ini juga dikarenakan adanya pengaruh dari suku bunga acuan yang bergerak meningkat. Tahun 2014 negara Indonesia mengadakan pemilu namun IHSG bergerak positif. Artinya pemilu memiliki pergerakan yang baik secara finansial dan ekonomis. Kuadran II tahun 2015, IHSG mengalmi pelemahan yang cukup tajam yang mana terdapat adanya potensi The Fed bergerak naik dan kurs rupiah mengalami pelemahan. Kemudian tahun-tahun selanjutnya, IHSG berangsur-angsur memperlihatkan kenaikan dan penurunan tipis kembali di semester II tahun 2018.

Dari hal diatas, krisis ekonomi pada tahun 2008 dapat menunjukkan adanya besar kecilnya pengaruh aliran modal. Sehingga bank sentral selaku otoritas moneter menjalankan tugasnya dalam menjaga stabilitas harga, dengan membuat inflation targeting framework agar tingkat inflasi jangka panjang dapat diantisipasi. Penurunan dan peningkatan kinerja IHSG dipasar modal yang dipengaruhi dari faktor lain juga dipengaruhii dari variabel makroekonomi yang sedang terjadi di dalam negeri. Sehingga peneliti ingin meneliti pengaruh variabel makroekonomi bagi IHSG. Pada penelitian kali ini, peneliti mengangkat judul "Analisis Pengaruh Variabel Makroekonomi Terhadap IHSG Setelah Terjadinya Krisis Subprime Mortgage".

Tujuan dari penelitian ini adalah untuk mengetahui pengaruh pengaruh 'siignifikan secara jangka panjang diantara variabel inflasi terhadap IHSG, untuk mengetahui pengaruhsignifikan didalam jangka panjang antara variiabel kurs terhadp IHSG, dan untuk mengetahui pengaruhyang signifikan dalam jangka panjang diantara variabel BI rate terhadap IHSG. Adapun manfaat dari penelitian ini untuk menjadi dasar dalam melakukan investasi di pasar modal, karena ini menjadi salah satu indikator kekuatan pertumbuhan perekonomian dalam negeri tanpa harus mengeluarkan modal yang banyak, tanpa harus waktu luang yang banyak dan tanpa harus memiliki sarana yang besar dalam menambah penghasilan tambahan. 


\subsection{Tinjaun Pustaka}

\subsubsection{Teori Indeks Harga Saham Gabungan (IHSG)}

Indeks terdefinisi sebagai pengukuran yang berbentuk statistik perubahan/pergerakan harga sekelompok instrumen keuangan jangka panjang (saham) yang ditentukan dengan parameter yang dipilih serta dimanfaatkan untuk berinvestasi di BEI. Kenaikan harga saham dapat menunjukan bahwa situasi pasar modal sedang mengalami uptrend atau bullish. Namun sebaliknya apabila harga saham turun maka situasi pasar modal mengalami downtrend atau bearish. IHSG dapat didefinisikan sebagai kegitan secara umum yang mencerminkan kgiatan di pasar modal [9]. Perkembangan perekonomian dalam negeri juga dipengaruhi oleh IHSG sebagai salah satu indikator. Pergerakan IHSG dapat disebabkan oleh beberapa indikator yang dapat dilihat melalui kondisi perekonomian dalam negeri seperti inflasii, nilai tukar(kurs) dan BI rate yang dikeluarkan oleh bank sentral sebagai salah satu kebijkan moneter.

Widodo (2011) pada pengujian ECM, hanya variable inflasi yang tidak memiliki pengaruh jangka pendek, namun kurs dan BI rate memiliki pengaruh jangka pendek, sedangkan dalam jangka Panjang, ketiga variabel tersebut memiliki pengaruh terhadap IHSG [10]. Sedangkan, Kusumawardani(2018) pada skripsinya, bahwa pada jangka pendek inflasi memiliki pengaruh signifikan negatif, sedangkan Inflasi dan BI Rate tidak ada pengaruh signifikan bagi IHSG. Pada jangka Panjang inflasi dan BI Rate terdapat pengaruh signifikan negatif sedangkan kurs tidak ada pengaruh signifikan [11].

\subsubsection{Variabel Makroekonomi}

Analisis yang ada pada teori makroekonomi lebih kepada cakupan yang agregat dan bersifat menyeluruh serta mengupas isu-isu yang lebih serius sering terjadi pada suatu perekonomian. Variabel makroekonomi memiliki imbas yang cukup besar terhadap pertumbuhan perekonomian suatu negara, apabila pemerintah tidak segera menanganinya. Terdapat dua lingkungan ekonomi yaitu, lingkungan ekonomi makro dan lingkungan ekonomi mikro. Didalam penelitian ini yang digunakan adalah ekonomi makro, diberikan alasan bahwa lingkungan ekonomi makro cakupannya lebih agregat (keseluruhan/makro) dan lebih cepat berpengaruh terhadap perekonomian. Banyaknya variabel makroekonomi, peneliti hanya memilih tiga variabel pada penelitian kali ini, antara lain inflasi, nilai tukar rupiah (kurs) dan suku bunga acuan (BI rate). Berikut peneliti sajikan kajian teori ketiga variabel makro sebagai berikut.

\section{a. Inflasi}

Inflasi dapat diartikan bahwa suatu fenomena yang mana terjadi naiknya harga barangbarang secara luas dengan skala waktu secara terus menerus serta berdampak pada naiknya harga - harga yang lain [12]. Adanya Inflasi yang mengalami kenaikan secara terus menerus mengakibatkan hal buruk terhadap perekonomian. Namun inflasi juga memberikan dampak yang menguntungkan bagi pengusaha ekspor. Inflasi memiliki beberapa jenis yang digolongkan dari beberapa kriteria yaitu, tingkat inflasi (inflasi ringan, sedang, berat atau sangat berat). Adanya harapan dari inflasi adalah inflasi yang stabil yang mana menjadi tanda dan syarat awal untuk pertumbuhan perekonomian yang dapat memberikan peningkatan tingkat kesejahteraan. Namun, apabila terjadi inflasi yang tidak stabil dan bahkan inflasi tinggi dapat memberikan dampak negatif pada tingkat kesejahteraan masyarakat. Bahkan menyebabkan meluasnya kemiskinan dan ketimpangan. Kondisi inflasi sedang mangalami kenaikan hingga dikatakan tinggi ini rata-rata sedang terjadi keadaan perekonomian yang overheated [13].

Investor sendiri dapat mempengaruhi perekonomian negara akan memilih menunggu kebijakan yang dikeluarkan oleh pemerintah agar segara mengatasi inflasi. Dari inflasi beban biaya yang investor tanggung akan lebih banyak, walaupun disisi lain jumlah output yang terjual meningkat, dari penjualan tidak memberikan keuntungan yang lebih banyak dan pengaruhnya 
pada deviden yang akan diterima oleh investor. Hal tersebut terbukti dari adanya penelitian Wismantara dan Darmayanti (2017), dari penelitian mereka hasil menunjukan bahwa variable inflasi memiliki pengaruh negatiif serta signifikan bagi IHSG [14]. Dikuatkan oleh Harsono dan Worokinasih (2018), variabel inflasi memiliki pengaruh negatif dan.tidak signifiikan terhadp IHSG [15].

\section{b. Nilai Tukar (Kurs)}

Kurs dapat memperlihatkan bahwa sebuah nilai mata uang dikatakan ke dalam mata uang asing [16]. Kurs, terdefinisi sebagai sebuah harga nilai mata uang negara bila ditukar mata uang asing. Kurs valas juga diartikan bahwa sejumlah uang domestik dapat mendapatkan sejumlah mata uang negara asing. Dapat diartikan secara singkat bahwa kurs merupakan selisih harga dari alat pembayaran yang berbeda dari kedua negara atau lebih. Bagi perusahaan yang terjun dalam bidang pasar internasional nilai tukar (kurs) menjadi hal yang terpenting. Karena apabila kurs depresiasi maka harga impor mengalami kenaikan sehingga menurunkan keuntungan suatu perusahaan. Menurunnya keuntungan suatu perusahaan, menyebabkan investor tidak tertarik untuk menginvestasikan uangnya pada perusahaan tersebut [17].

Kurs bisa mempengaruhi secara luas bagi suatu perekonomian negara khususnya yang ter jadi pada pasar modal, dikarenakan kurs menjadi indikator terpenting bagi pertumbuhan perekonomian. Kurs berperanpenting dikarenakan dapat mempengaruhi harga barng di dalam negeri relatiif terhadp harga barng luar negerii [18]. Sehingga pergerakan kurs rupiah menjadikan pengaruh keuntungan sebuah perusahaan dan mempengaruhi daya tarik investor dalam berinvestasi di sebuah perusahaan. Terutama pada perusahaan yang mengharuskan melakukan pemasokan bahan baku dari luar negeri (impor) karena kurs rupiah juga dapat dipengaruhi oleh faktor eksternal. Misalnya tahun 2018-2019 kurs rupiah mengalami pelemahan karena adanya perang dagang AS-China, kebijakan dalam negeri pun berusaha mengendalikan tingkat inflasi agar tetap stabil. Dilihat dari perkembangan pada pasar modal IHSG melemah dan kurs terhadap dollar AS juga mengalami pelemahan.

Penlitian pengaruh kurs bagi IHSG dilakukan Kusuma (2016), kurs memiliki pengaruh signifikan bagi IHSG dan menunjukan tanda positif, yang artinya searah. Yang mana, artinya jika kurs depresiasi, IHSG akan melemah dan sebaliknya jika Kurs apresiasi, IHSG akan meningkat [19]. Kemudian Pahlevi (2019) Kurs signifikan dan hubungannya dinmis berarah positif pada IHSG [20].Berbeda dengan penelitian Alianty (2016), kurs tidak memiliki pengaruh signifikan bagi IHSG[21].

\section{c. BI Rate}

BI rate adalah suku bunga kebijakan yang memperlihatkankan prilaku dari kebiijakan moneter, kemudian dumumkan pada publik [22]. Suku bunga acuan menjadi salah satu strategi didalam stabilisasi perekonomian dalam negeri. Karena BI rate dapat menurunkan tingkat inflasi tinggi yang menyebaban naiknya ketimpangan, kemiskinan dan penurunan tingkat kesejahteraan. Selain itu, BI rate dapat memulihkan nilai tukar rupiah kembali. Karena apabila nilai tukar rupiah (kurs rupiah) melemah akan berakibat hutang luar negeri yang ditanggung pemerintah meningkat dan neraca pembayaran mengalami defisit serta dapat berakibat menurunkan ekspor. Pelemahan kurs rupiah ini juga berakhibat dari adanya inflasi yang tinggi. Selain itu, BI rate memiliki peran penting dalam berinvestasi khususnya pada pergerakan harga saham. Adanya perubahan BI rate akan memberikan pengaruh kepada masyarakat untuk berinvestasi. Apabila BI rate menunjukan kenaikan maka masyarakat lebih memilih investasi di bank baik dalam bentuk tabungan ataupun deposito, masyarakat lebih tergiur adanya bunga simpanan yang tinggi, sehingga pergerakan dalam pasar modal akan menurun. Sebaliknya, apabila BI rate menunjukan penurunan masyarakat lebih melakukan untuk membeli saham di pasr modal, kemudian harga saham akan meningkat. Harga pada surat berharga menunjukan kenaikan ataupun penurunan dilihat daritingkat BI rate[23].

Kenaikan biaya modal dapat disebabkan dari tingginya tingkat bunga, sehingga perusahaan mengalami pengembalian yang menjadi aba-aba investor dari tabungan yang 
menunjukan kenaikan [24]. Tingginya tingkat bunga dapat berpengaruh terhadap present value keuangan sebuah perusahaan, maka tidak dapat menarik peluang untuk melakukan berinvestasi. Besar kecilnya tingkat bunga dan IHSG mempunyai suatu kaitan yang berlawanan, artinya tidak memiliki keterkaitan positif (hubungan negatif) [13]. Naiknya suatu bunga maka harga saham dipasar modal akan menurun [25]. Perubahan pada suatu ketetapan kebijakan moneter memberikan pengaruh adanya perubahan harga produk di pasar modal. Teori tersebut diperkuat oleh adanya penelitian dari Yudhanto (2015), meneliti yang hasilnya terdapat pengaruh negatif dan signifikan antara BI rate bagi IHSG pada jangka panjang [26]. Kemudian diperkuat oleh Yustisia(2016)hasil penelitiannya, BI Rate berpengaruh signifikan, tapi bertanda negative bagi IHSG [27].

\subsection{Kerangka Penelitian}

Dalam penelitian ini dapat dibuat skema untuk menjelaskan secara garis besar suatu alur penelitian berdasarkan teori dan sesuai dari menggunakan variabel terikat dan variabel bebas dipenelitian ini. Berikut kerangka berfikir dalam penelitian ini :

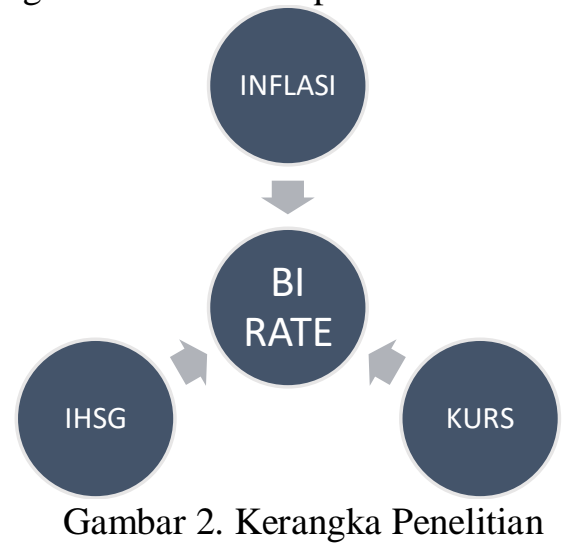

\section{METODE PENELITIAN}

Dalam penelitian ini menggunakan periode tahun awal pengembalian perekonomian setelah terjadinya krisis moneter yang bersumber dari krisis subprime mortgage AS, yaitu dari tahun 2009 - 2019. Penelitian menggunakan data bersifat kuantitatiif. Data berjumlah 44 yang diambil secara kuartalan selama 11 tahun dari setiap variabel. Alat pengolahan berupa eviews 10 . Teknik pengumpulan data menggunakan dokumen variabel BI Rate, inflasi adn kurs didapatkan dari situs Bank Indonesia. Data IHSG didapatkan melalui situs pasar modal business insider.

Penelitian ini menggunakan metode analisis model error correction model (ECM). Sebelum melakukan uji ECM, peneliti harus memperhatikan satuan dalam variabel terlebih dahulu. Variabel - variabel yang digunakan oleh peneliti memiliki satuan yang berbeda. Sehingga sebelum melakukan pengujian, penelitiakan menyamakan satuan dengan menggunakan log. Setelah diformulasikan satuan sama maka dapat melakukan beberapa langkah untuk pengujian ECM yang diestimasi dari model $O L S$. Sebelum melakukan estimasi dengan model ini maka harus melewati tahapan uji akar unit stasioner dan uji kointegrasi. Setelah tahapan tersebut, model ECM menggunakan persamaan model sebagai berikut :

$$
D(Y)_{t}=\beta_{0}+\beta_{1} D(X 1)+\beta_{2} D(X 2)+\beta_{3} D(X 3)+E C T(-1)_{t}+u
$$

Keterangan :

$\mathrm{Y}_{\mathrm{t}} \quad$ : Variable IHSG

$D X_{1} \quad$ : Variabel Tingkat Inflasi 


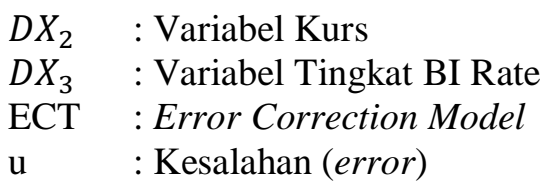

\section{HASIL DAN PEMBAHASAN}

\subsection{Uji Stationer}

Uji stasioner pada penelitian ini menggunakan pengujian stasioner degnan metode Augmented Dickey-Fuller (ADF). Dapat diketahui, hasil ADF p-value< tingkat alfa 0.05, maka variabel stasioner. Dari uji stasioner ditemukan bahwa hanya variabel .Indeks Harga Saham Gabungan (IHSG) yang lulus d tingkat level. Sedangkan variabel lainnya tidak lulus ditingkat level.

Tabel 1. Uji Stasioner

\begin{tabular}{|c|c|c|c|c|c|c|}
\hline \multirow{2}{*}{ VARIABEL } & \multicolumn{3}{|l|}{ LEVEL } & \multicolumn{3}{|c|}{ 1st DIFFERENCE } \\
\hline & ADF & Prob. & Keterangan & ADF & Prob. & Keterangan \\
\hline IHSG & -5.196823 & 0.0001 & Stasioner & $\begin{array}{l}- \\
6.366308\end{array}$ & 0.0000 & Stasioner \\
\hline Inflasi & -2.626899 & 0.0955 & $\begin{array}{l}\text { Tidak } \\
\text { Stasioner }\end{array}$ & $\begin{array}{l}-7.767386 \\
\end{array}$ & 0.0000 & Stasioner \\
\hline Kurs & -0.507688 & 0.8797 & $\begin{array}{l}\text { Tidak } \\
\text { Stasioner }\end{array}$ & $-\overline{6}-251862$ & 0.0000 & Stasioner \\
\hline BI Rate & -1.944313 & 0.3096 & $\begin{array}{l}\text { Tidak } \\
\text { Stasioner }\end{array}$ & 4.402478 & 0.0011 & Stasioner \\
\hline
\end{tabular}

Sumber : data diolah dengan eviews 10

Sehingga dilakukan uji pada tiap variabel kedalam posisi first difference. Hasil yang diperoleh bahwa semua variabel diketahui sudah stasioner, karena nilai probabilitas pada $1^{\text {st }}$ difference sudah memenuhi sarat uji stasioner atau lebih kecil dari tingkat alpha 5 persen. Sehingga, karena semua variabel baik terikat ataupun bebas telah lolos atau stasioner pada diferensi pertama, jadi tidak memerlukan untuk melanjutkan uji stasioner diferensiasi kedua.

\subsection{Uji Kointegrasi}

Untuk mengetahui bahwa data ada hubungan keseimbangan dalam jangka panjang maka digunakan uji kointegrasi. Penelitian ini memakai metode engle - grangercointegration test. Syarat yang harus dipenuhi ialah nilai residual wajib stasioner. Sehingga data dapat dikatakan lulus uji kointegrasi. Metode pengujian kointegrasi EG-ADF dilakukan dengan menggunakan dua tahapan. Tahap pertama, dengan mengestimasi model regresi OLS, yang mana hasil dari estimasi $O L S$ digunakan untuk melihat jangka panjang. Kemudian untuk tahap kedua dilakukan pengujian kointegrasi dari hasil regresi secara $O L S$ dan dapat memperoleh residual. Sehingga dapat dilihat hasil residual sebagai berikut :

Tabel 2. Hasil Running Dengan "none" pada Eviews10

\begin{tabular}{|l|l|l|l|l|}
\hline \multicolumn{6}{|l|}{ UJI STASIONERITAS RESIDUAL } \\
\hline \multirow{2}{*}{ Var. } & \multirow{2}{*}{ t-Statistik } & \multirow{2}{*}{ Prob. } & $\begin{array}{l}\text { Nilai Kritis } \\
\text { MacKinnon }\end{array}$ & \multirow{2}{*}{ Ket. } \\
\cline { 4 - 5 } & & & $\mathbf{5 \%}$ & \\
\hline ADF & -6.775360 & 0.0000 & -2.931404 & Stasioner \\
\hline
\end{tabular}

Sumber : data diolah dengan eviews 10 
Table diatas merupakan hasil setelah uji $A D F$ dilakukan pada tingkat level, untuk menguji residual jangka panjang. Dari pengujian diketahui bahwa hasil $A D F$ test menghasilkan nilai sebesar -6.775360 dan nilai kritis tingkat kepercayaan 5 persen menghasilkan bahwa menolak $H_{0}$ atau bahwa $A D F$ Test $>$ dari nilai t-tabel atau dengan membaca hasil melalui nilai probabilitas yaitu 0.0000 yang artinya $0.0000<0,05$. Sehingga hasil dari nilai residualnya sesuai yang diinginkan yaitu dalam persamaan nilai residual telah stasioner. Hal tersebut membuktikan, data yang diuji ada hubungan signifikan atau berkointegrasi dijangka panjang diantara IHSG dan variabel-variabel yang mempengaruhinya yaitu inflasi, kurs dan BI Rate

\subsection{Uji Asumsi Klasik}

\section{a. Normalitas}

Melakukan pengujian normalitas dengan ketentuan nilai Prob. Jarque-Bera> 0.05. Dari hasil perhitungan terlihar bahwa nilai probabilitas $0,981506>0.05$. Nilai tersebut menunjukkan bahwa model berdistribusi normal.

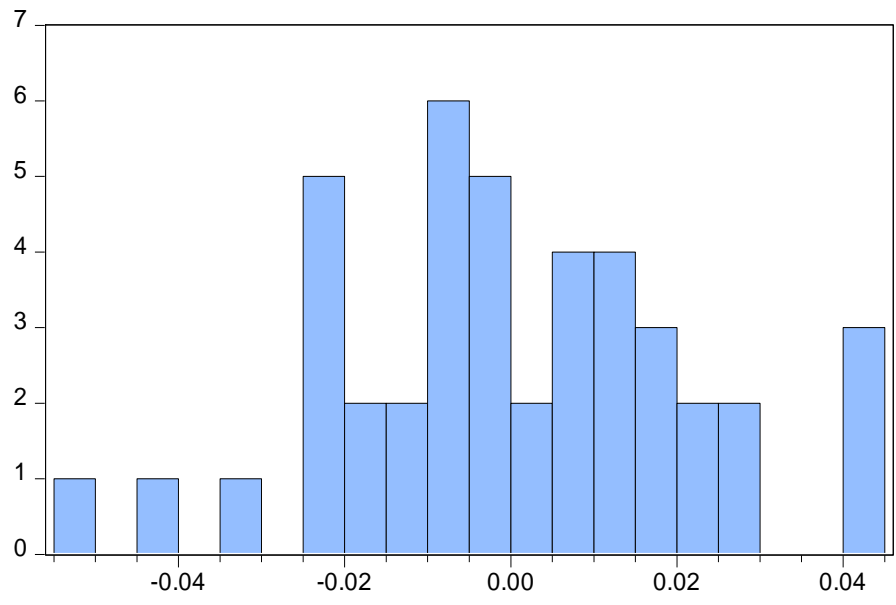

\begin{tabular}{|lr}
\hline \multicolumn{2}{l}{ Series: Residuals } \\
Sample 2009Q2 2019Q4 \\
Observations 43 \\
Mean & $-1.57 \mathrm{e}-18$ \\
Median & -0.001904 \\
Maximum & 0.043948 \\
Minimum & -0.053139 \\
Std. Dev. & 0.021377 \\
Skewness & -0.068302 \\
Kurtosis & 2.953341 \\
& \\
Jarque-Bera & 0.037334 \\
Probability & 0.981506 \\
\hline
\end{tabular}

Gambar 3. Hasil Uji Normalitas pada Model ECM

Sumber : data diolah dengan eviews 10

\section{b. Uji Heteroskedastisitas}

Hasil pengujian heteroskedastisitas menggunakan metode Breusch Pagan Godfrey dari model ECM yakni, Uji heteroskedastisitas metode Breusch Pagan Godfrey model dari ECM menghasilkan probabilitas pada Obs*R-square bernilai 0.9867 ( $>0,05)$. Sehingga pada pengujian heteroskedastisitas dari model ECM menunjukan bahwa $H_{0}$ diterima artinya bahwa model penelitian yang digunakan lolos uji heteroskedastisitas atau tidak terjadi heteroskedastisitas.

Tabel 3. Uji Heterokedastisitas

Heteroskedasticity Test: Breusch-Pagan-Godfrey

\begin{tabular}{llll}
\hline \hline F-statistic & 0.076866 & Prob. F(4,38) & 0.9889 \\
Obs*R-squared & 0.345125 & Prob. Chi-Square(4) & 0.9867 \\
Scaled explained SS & 0.263242 & Prob. Chi-Square(4) & 0.9921 \\
\hline \hline
\end{tabular}

Sumber : data diolah dengan eviews 10

\section{c. Uji Multikolinearitas}

Dari pengujian uji multikolinearitas model Variance Inflation Factor (VIF) menunjukan bahwa tiap variabel perubahan yang telah teruji menunjukan hasil yang tidak angka yang lebih dari angka 10. Sehingga model ECM dapat dikatakan lolos uji dari masalah multikolinearitas. 
Variance Inflation Factors

Tabel 4. Uji Multikolinearitas

\begin{tabular}{llll}
\hline \hline Variable & $\begin{array}{l}\text { Coefficient } \\
\text { Variance }\end{array}$ & $\begin{array}{l}\text { Uncentered } \\
\text { VIF }\end{array}$ & $\begin{array}{l}\text { Centered } \\
\text { VIF }\end{array}$ \\
\hline \hline C & $1.24 \mathrm{E}-05$ & 1.059821 & NA \\
D(INFLASI) & 0.001217 & 1.302897 & 1.290522 \\
D(KURS) & 0.051036 & 1.717751 & 1.702712 \\
D(BI_RATE) & 0.014123 & 1.283439 & 1.259964 \\
ECT(-1) & 0.002130 & 1.678513 & 1.678383 \\
\hline \hline
\end{tabular}

Sumber : data diolah dengan eviews 10

\section{d. Uji Autokorelasi}

Dari table dibawah, pengujian autokorelasi menggunakan metode $L M$ test pada model ECM diketahui Prob.Chi Square(2) bernilai 0,6205. Ini berarti nilai probabilitas Chi Square>tingkat alfa 0,05. Artinya pengujian kaliini lolos uji autokorelasi, artinya, pada pengujian ini masuk dalam kriteria BLUE.

Tabel 5. Uji Autokorelasi (LM Test)

Breusch-Godfrey Serial Correlation LM Test:

\begin{tabular}{llll}
\hline \hline F-statistic & 0.408543 & Prob. F(2,36) & 0.6677 \\
Obs*R-squared & 0.954304 & Prob. Chi-Square(2) & 0.6205 \\
\hline \hline
\end{tabular}

Sumber : data diolah dengan eviews 10

\subsection{Persamaan dalam Jangka Panjang}

Dalam persamaan ini dapat mengetahui periode yang memiliki kemungkinan untuk melihat dari adanya penyesuaian hasil secara maksimal dalam setiap terjadi perubahan. Berikut hasil regresi jangka panjang :

Table 6. Hasil Persamaan Jangka Panjang

\begin{tabular}{|l|l|l|l|}
\hline VARIABEL & KOEFISIEN & t-Stat. & Prob. \\
\hline C & -0.105709 & -0.124598 & 0.9015 \\
\hline INFLASI & 0.177274 & 1.414468 & 0.1650 \\
\hline KURS & 1.055191 & 5.354067 & 0.0000 \\
\hline BI RATE & -0.821875 & -3.232932 & 0.0025 \\
\hline
\end{tabular}

Sumber : diolah dengan eviews 10.

Dari tablel 4, pengolahan data dengan eviews 10 menghasilkan sebuah persamaan jangka panjang sebagai berikut :

$$
I H S G=-0.1057+0.1772^{*} I N F L A S I+1.0551^{*} K U R S-0.8218^{*} B I_{\text {Rate }}+e
$$




\subsection{Persamaan Dalam Jangka Pendek}

Tabel 7. Hasil Persamaan Jangka Pendek

\begin{tabular}{|l|l|l|l|}
\hline VARIABEL & KOEFISIEN & t-Stat. & Prob. \\
\hline C & 0.0156 & 4.4342 & 0.0001 \\
\hline D(INFLASI) & 0.0117 & 0.3380 & 0.7372 \\
\hline D(KURS) & -0.7898 & -3.4961 & 0.0012 \\
\hline D(BI_RATE) & -0.1577 & -1.3270 & 0.1924 \\
\hline ECT(-1) & -0.1656 & -3.5900 & 0.0009 \\
\hline R-squared & 0.6564 & \\
\hline Adj. R-Squared & 0.6203 & & \\
\hline F-statistik & 18.1558 & \\
\hline Prob. F Statistik & 0.0000 & \\
\hline $\begin{array}{l}\text { Durbin Watson } \\
\text { Statistik }\end{array}$ & 1.7394 & \\
\hline
\end{tabular}

Sumber :diolah dengan eviews 10 .

Table 3 menunjukan pengolahan data dengan eviews 10 menghasilkan sebuah persamaan jangka pendek yakni :

$$
\begin{aligned}
D(I H S G)= & 0.0156+0.0117^{*} D(I N F L A S I)-0.7898^{*} D(K U R S)-0.1577^{*} D\left(B I_{\text {Rate }}\right) \\
& -0.1656^{*} E C T(-1)
\end{aligned}
$$

\subsection{Uji Goodnes Of Fit}

Dari tabel 3, didapatkan nilai koefisien determinan $\left(\mathrm{R}^{2}\right)$ sebesar 0.6564 ,artinya ada pengaruh variiabel bebas kepada variabel terikat sebesar 65,64 persen dan pengaruh dari luar variabel penelitian ini sebesar 34,36 persen.

\subsection{Pembahasan Hasil Uji Jangka Pendek dan Jangka Panjang}

Dari hasil pengujian dalam jangka pendek diketahui nilai koefisien Error Correction Term (ECT) model tersebut telah signifikan yang dilihat dari nilai $0,0009<0,05$ artinya bahwa nilai Error Correction Term (ECT) yang digunakan telah valid. Untuk nilai keseimbangannya 0.1656 artinya bahwa proses penyesuaian terhadap ketidakseimbangan perubahan IHSG periode 2009 hingga 2019 relatif lambat. Nilai koefisien ECT sebesar -0.1656, artinya kurang lebih 16,56 persen yang tidak sesuai diantara IHSG actual dan keinginan IHSG yang diharapkan dapat tereliminasi pada satu periode.

\section{a. Pengaruh Inflasi Terhadap IHSG}

Hasil pengujian yang didapat, variabel inflasi dalam jangka pendek maupun jangka panjang tidak memiliki pengaruh signifikan pada IHSG. Nilai koefisien pada jangkapendek dan Panjang bertandapositif, artinya memiliki gerakan searah. Tiap perubahan 1 persen variabel inflasi memberikan perubahan 17,72 persen pada jangka panjang dan 1,18 persen pada persamaan ECM jangka pendek. Ketika inflasi menunjukan kenaikan atau penurunan tidak mempengaruhi kenaikan atau penurunan IHSG, sebab probabilitasnya bernilai (0.7372 pada jangka pendek dan 0.1650 pada jangka Panjang yang mana >0,05). Berdasarkan data kinerja IHSG 10 tahunan sejak 2009-2019, dalam jangka pendek, kinerja pasar saham selalu berfluktuasi. Dibuktikan ketika ada masa penurunan di awal tahun, kinerja IHSG 10 tahunan pun masih tertekan, yaitu antara $8,75 \%, 11,32 \%$ hingga 16,41\%. Meski demikian kinerja ini juga jauh lebih baik dibanding inflasi di masa yang sama.[28]. 
Adanya tanda positif tersebutkarena berlebihan barang demand atas supplyyang ada. Sehingga, beban pada naiknya biaya diberikan konsumen dan ukuran yang lebih banyak, darisini laba perusahaan akan naik serta dapat menaikan skill dalam membayarkan deviden yang diikuti pada harga saham bernilai positif[29]. Pengujiandalam waktusetelah terjadinyakrisis subrime mortgage, inflasi dalam jangka pendek maupun jangka panjang tidak memiiliki pengaruh signifikan pada IHSG. Sejalan denganpenelitian Sihombing dan Rizal (2014), inflasi tidak ada pengaruh signifikanbagi IHSG pada jangka pendek maupun jangka Panjang [30].

\section{b. Pengaruh Kurs Terhadap IHSG}

Variable kurs pada jangka pendek memiliki pengaruh signifikan terhadap IHSG sebab probabilitas yang bernilai $0.0012(<0,05)$, koefisiennya bernilai -0.7898 artinya apabila kurs meningkat sebesar 1 persen akan memberi pengaruh penurunan IHSG sebesar 78,98 persen dan tanda negatif berarti memiliki gerakan arah yang berlawanan. Jika kurs naik, IHSG akanturun dan sebaliknya, bila kurs turun IHSG naik. IHSG juga dipengaruhi oleh kurs secara jangka panjang,sebab probabilitas bernilai $0,000 \quad(<0,05)$. Pada jangka Panjang koefisien kurs $(1,055191)$ tiap terdapat perubahan 1 persen variabel Kurs akan memberikan perubahan 105,51 persen dan bertanda positif berarti memiliki arah yang sama.

Terdapat hubungan secara dinamis diantara kurs bagi IHSG, maka pergerakan kurs akan mempengaruhi IHSG.Pada kurs jangka pendekkoefisien bertanda negatif, artinya terdapat dampak langsung ketika kurs menguat dan terjadi pergerakan IHSG menurun. Jangka panjang variabel kurs koefisein bertandapositif, artinya pada jangka panjang kurs terhadap IHSG memiliki gerakan searah. Jika kurs rupiah sedang terjadi apresiasi, maka IHSG akan menunjukan peningkatan. Sebaliknya, jika kurs rupiah terjadi depresiasi, IHSG turun. Sehingga ketika rupiahmengalami penguatan, dapat memepengaruhi investor untuk lebih menanam saham di dalam negeri dan dapat memberikan keuntungan bagi perusahaan yang bersangkutan.

Adanya pengaruh negatif pada jangka pendek sejalan pada penelitian Santoso (2018)dan pada jangka panjang memiliki pengaruh signifikan, namun bertanda negative [31]. Penelitian lain, dilakukan Mahdi dan Kaluge (2010)kurs memilikii pengaruh signifiikan dalam jangkapendek bertanda dan jangka panjang terhadap IHSG[32]. Kemudian penelitian tersebut dikuatkan oleh Ranto (2019)bahwa pada uji ECM yaitukurs memilikii pengaruh signifikan dalam jangkapendek danjangka panjang terhadap IHSG[33].

\section{c. Pengaruh BI Rate bagi IHSG}

Variable BI ratepada jangka pendek tidak memiliki pengaruh signifikan bagi IHSG sebab probabilitas bernilai $0.1924(>0,05)$ dan nilai koefisien sebesar -0.1577 , artinya setiap BI Rate meningkat 1 persen akan memberikan pengaruh penurunan IHSG sebesar 15,77 persen. Pada jangka panjang memiliki pengaruh signifikan terhadap IHSG sebab probabilitas bernilai $0.0025(<0,05)$ dan nilai koefisien sebesar -0.8218 , artinya setiap BI rate meningkat 1 persen akan memberikan pengaruh penurunan IHSG sebesar 82,19 persen. Tanda negatif pada nilai koefisien artinya memiliki gerakan arah yang berlawanan. Jika sedang terjadi ketetapan kebijakan BI rate naik IHSG akan menurun dan sebaliknya jika kebijkan BI rate menurun IHSG akan naik. Karena jika BI rate naik, maka masyarakat akan lebih bersemangat untuk menabung, dan jika BI Rate naik terusmenerus dapat mendorong kenaikan bunga pada bank serta dapat memperburukkinerja dipasar modal(IHSG).Sebaliknya, BI Rate menurun secara terus menerus masyarakat akan tidak tertarik pada menabung di Lembaga keuangan bank, namun lebih tertarik berinvestasi di pasar modal.

Pada buku "Makroekonomi" karya Mankiw, adanya jumlah barang modal tergantung dengan tingkat bunga, yang mana digunakan dalam membiayai dana untuk biaya investasi. Pengaruh secara jangka panjang dapat terlihat secara nyata bahwa IHSG setiap tahun menunjukan kenaikan yang nyata. Pada akhir tahun 2009, IHSG bernilai 2,534.36 dan diakhir tahun 2019 menjadi 6,299.54. Sedangkan BI rate dari tahun 2009 hingga 2019 mengalami naik turun. Namun dalam jangka panjang BI rate dapat dibilang mengalami penurunan. Hal tersebut terlihat bahwa akhir tahun 2009, BI rate sebesar 7,75 persen dan akhir tahun 2019 sebesar 5 
persen. Sehingga, dalam berinvestasi berupa IHSG pada jangka panjang memberikan pengaruh yang cukup menjanjikan bagi investor. Walaupun disisi lain memiliki resiko yang cukup besar apabila investor tidak hati-hati dalam pemilihan emiten.

Kemudian, skripsi Normalita (2018), hasil estimasi jangka pendek kurs memiliki pengaruh negatif dan tidak signifikan dijangka pendek, pada jangka Panjang berpengaruh negatif dan signifikan bagi IHSG[34]. Penelitian tersebut searah dengn Maryatmo (2010) hasilnya dengan model ECM bahwa pergerakan variabel BI rate bagi IHSG memiliki pengaruh negatif dijangka pendek dan jangka panjang[35].

\section{KESIMPULAN}

Setelah terjadinya krisis subprime mortgagetahun 2008 yang terjadi di Indonesia, kemudian ditahun 2009 merupakan tahun awal kebangkitan negara Indonesia. Jadi, penulis menggunakan periode dalam kuartal dari tahun 2009 hingga 2019 (11 tahun dengan 44 data). Metode, dengan menggunakan model ECM, yang menghasilkan nilai ECT yang sudah terpenuhi sesuai dengan kriteria. Sehingga model ini tepat digunakan dalam melakukan analisis adanya variabel yang mempengaruhi, yaitu Inflasi, Kurs dan BI Rate bagi variabel yang terpengaruhi atau IHSG.

Dari pengujian diatas, didapatkan kesimpulan bahwa pengujian ini memperlihatkan bahwa adanya kointegrasi antar variabel bebas dan variabel terikat dan didapatkan bahwa modelterbebas dari masalah asumsi klasik. Dengan kesimpulan sebagai berikut: 1) inflasi tidak memiliki pengaruh signifikan dalam jangka pendek maupun jangka panjang bagi IHSG di pasar modal. Sehingga, inflasit tidak menjadikan pertimbangan investor untuk berinvestasi. 2) Kurs memiliki pengaruh signifikan baik jangka pendek ataupun jangka panjang bagi IHSG di pasar modal dan dalam penelitian tersebut terlihat adanya keseimbangan. Karena, terdapat hubungan yang dinamis antara kurs bagi IHSG. 3) BI rate tidak memiliki pengaruh signifikan bagi IHSG dalam jangka pendek. Namun dalam jangka panjang memiliki pengaruh signifikan bagi IHSG di pasar modal.

\section{SARAN}

Dalam penelitian ini diharapkan menjadikan salah satu pertimbangan bagi para investor sebelum memutuskan untuk berinvestasi dan investasi IHSG sangat memberikan keuntungan yang besar dalam jangka panjang apabila investor tepat dalam pembelian emiten saham. Penelit sadar bahwa penelitian banyak kekurangan atas keterbatasan bahan yang dipergunakan. Bahan yang digunakan sebatas menganalisis variabel makroekonomi sebagai alat ukur terhadap IHSG. Mungkin, penelitian selanjutnya bisa menggunakan variabel dan faktor lain dalam mempengaruhi IHSG seperti, variabel jumlah uang beredar, variable tingkat pendapatan nasional, variabel ekspor atau faktor-faktor lainnya seperti tingkat pengangguran, dan tingkat korupsi.

\section{DAFTAR PUSTAKA}

[1] Y. Ardana, "Pengaruh Variabel Makroekonomi Terhadap Indeks Saham Syariah di Indonesia: Model ECM," Esensi J. Bisnis dan Manaj., vol. 6, no. 1, pp. 17-30, 2016.

[2] G. T. Mahardika, H. Siregar, and D. B. Hakim, "Analisis Fluktuasi Dollar Amerika Serikat Terhadap Rupiah di Saat dan Setelah Krisis Subprime Mortgage 2007-2013," Signifikan J. Ilmu Ekon., vol. 3, no. 2, pp. 169-184, 2014. 
[3] R. Z. Agha, "Analisa Pengaruh Krisis Subprime Mortgage Terhadap Indikator Return Saham Industri Konsumsi yang Terdaftar di Bursa Efek Indonesia," J. TEKUN, vol. 4, no. 1, pp. 143-157, 2013.

[4] H. Umar, "Dampak Krisis Sub-Prime Mortgage Terhadap Ekonomi Makro Dan Pasar Modal di Indonesia," JRB-Jurnal Ris. Bisnis, vol. 1, no. 1, pp. 8-18, 2019.

[5] N. Purbawati and I. Dana, "Perbandingan Volatilitas Indeks Harga Saham Gabungan (IHSG) Sebelum dan Setelah Krisis Subprime Mortgage," E-Jurnal Manaj. Univ. Udayana, vol. 5, no. 2, pp. 1014-1042, 2016.

[6] R. D. Astuti, "Analisis Makro Kinerja Pasar Modal Indonesia Dengan Pendekatan Error Correction Model (ECM),” Econ. J. Emerg. Mark., vol. 6, no. 1, pp. 13-32, 2001.

[7] K. Listriono and E. Nuraina, "Peranan Inflasi, Bi Rate, Kurs Dollar (Usd/Idr) dalam Mempengaruhi Indeks Harga Saham Gabungan (IHSG)," J. Din. Manaj., vol. 6, no. 1, pp. 73-83, 2015.

[8] Aditya, B. M. Sinaga, and T. A. Maulana, "Pengaruh Indeks Bursa Luar Negeri, Indikator Makroekonomi dan Krisis Ekonomi Global Terhadap Indeks Harga Saham Gabungan di Indonesia,” J. Apl. Manaj. dan Bisnis, vol. 4, no. 2, pp. 284-295, 2018.

[9] M. Mahdi and D. Kaluge, "Pengaruh Tingkat Suku Bunga (BI Rate) dan Kurs Dollar AS Terhadap Indeks Harga Saham Gabungan (IHSG) dengan Menggunakan Metode Error Correction Model (ECM)," JEP - J. Ekon. Pembang., vol. 8, no. 2, pp. 307-314, 2010.

[10] S. Widodo, "Pengaruh Variabel Makroekonomi Terhadap Indeks Harga Saham: Studi Kasus IHSG Periode Januari 2006 - Desember 2010," Universitas Islam Negeri Syarif Hidayatullah Jakarta, 2011.

[11] Safitri Kusumawardhani, "Analisis Pengaruh Variabel Makroekonomi Terhadap Indeks Harga Saham Gabungan Periode 2008.I-2016.IV," Universitas Muhammadiyah Surakarta, 2018.

[12] I. P. W. P. Asmara and A. A. G. Suarjaya, "Pengaruh Variabel Makro Ekonomi Terhadap Indeks Harga Saham Gabungan,” E-Jurnal Manaj. Unud, vol. 7, no. 3, pp. 1397-1425, 2018.

[13] S. S. Kewal, "Pengaruh Inflasi, Suku Bunga, Kurs, dan Pertumbuhan PDB Terhadap Indeks Harga Saham Gabungan,” J. Econ., vol. 8, no. 1, pp. 53-64, 2012.

[14] angga Y. W. dan N. P. A. Darmayanti, "Pengaruh Nilai Tukar, Suku Bunga dan Inflasi Terhadap Indkes Harga Saham Gabungan Di Bursa Efek Indonesias," vol. 6, no. 8, pp. 4391-4421, 2017.

[15] A. R. H. dan S. Worokinasih, "Pengaruh Inflasi, Suku Bunga, Dan Nilai Tukar Rupiah Terhadap Indeks Harga Saham Gabungan (Studi pada Bursa Efek Indonesia Periode 2013-2017)," J. Adm. Bisnis, vol. 60, no. 2, pp. 102-110, 2018.

[16] S. Sukirno, Makro Ekonomi Teori Pengantar, Ketiga. Jakarta: Rajawali Pers, 2013.

[17] M. M. Syarif and N. Asandimitra, "Pengaruh Indikator Makro Ekonomi dan Faktor Global Terhadap Indeks Harga Saham Gabungan (IHSG)," J. Stud. Manaj., vol. 9, no. 2, pp. 142-156, 2015.

[18] M. S. Dewi, “Analisis Pengaruh Variabel Makroekonomi Terhadap Inflasi di Indonesia Sebelum dan Sesudah Diterapkannya Kebijakan Inflation Targeting Framework Periode 2002:1 - 2010:12," Media Ekon., vol. 19, no. 2, 2011. 
[19] I. Kusuma and I. Badjra, "Pengaruh Inflasi, Jub, Nilai Kurs Dollar dan Pertumbuhan GDP Terhadap IHSG di Bursa Efek Indonesia," E-Jurnal Manaj. Univ. Udayana, vol. 5, no. 3, pp. 1829-1858, 2016.

[20] R. W. Pahlevi, "Sensitivitas Makroekonomi dan Moneter Terhadap IHSG," AFRE, vol. 2, no. 1, pp. 65-72, 2019.

[21] H. Alianty, "Pengaruh Inflasi, Nilai Tukar Rupiah (Kurs Tengah Bi), PDB, Harga Emas Dunia dan Harga Minyak Mentah Dunia Terhadap IHSG Periode 2009-2014,” J. Eksek., vol. 13, no. 2, pp. 345-363, 2016.

[22] M. T. Sahetapy and P. S. J. Kennedy, "Pengaruh Variabel-Variabel Ekonomi Makro: Nilai Tukar Rupiah/USD, BI Rate, Inflasi, dan Harga Minyak Dunia Terhadap Return Saham Sektor Manufaktur Periode 2006-2015 2006-2015," Fundam. Manag. J., vol. 2, no. 2, pp. 115-129, 2017.

[23] L. F. Triani, "Faktor-Faktor Yang Mempengaruhi Perubahan Indeks Harga Saham di Jakarta Islamic Index Selama Tahun 2011,” J. Organ. dan Manaj., vol. 9, no. 2, pp. 162178, 2011.

[24] S. Y. Wismantara and N. P. A. Darmayanti, "Pengaruh Nilai Tukar, Suku Bunga dan Inflasi Terhadap Indeks Harga Saham Gabungan di Bursa Efek Indonesia," E-Jurnal Manaj., vol. 6, no. 8, pp. 4391-4421, 2017.

[25] N. K. Suriyani and G. M. Sudiartha, "Pengaruh Tingkat Suku Bunga, Inflasi Dan Nilai Tukar Terhadap Return Saham di Bursa Efek Indonesia," E-Jurnal Manaj. Univ. Udayana, vol. 7, no. 6, pp. 3172-3200, 2018.

[26] Y. dan M. R. Tri, "Analisis Pengaruh Inflasi, Bi Rate, Indeks Dow Jones dan Kurs Terhadap Indeks Harga Saham Gabungan (IHSG) Periode Januari 2011 - Desember 2015," Universitas Muhammadiyah Surakarta, 2017.

[27] N. Yustisia, "Faktor - Faktor yang Memengaruhi Pergerakan Indeks Harga Saham Gabungan di Bursa Efek Indonesia," J. bisnis dan Komun., vol. 3, no. 2, pp. 38-43, 2016.

[28] A. Widianto, "Sejarah Kinerja IHSG 10 Tahun," Bolasalju, 2017. [Online]. Available: https://bolasalju.com/artikel/sejarah-kinerja-ihsg-10-tahun/.

[29] Y. Jayanti, "Pengaruh Tingkat Inflasi, Tingkat Suku Bunga SBI, Nilai Tukar Rupiah, Indeks Dow Jones, dan Indeks Klse Terhadap Indeks Harga Saham Gabungan (Ihsg) Studi Pada Bursa Efek Indonesia Periode Januari 2010 - Desember 2013,” J. Adm. Bisnis, vol. 11, no. 1, pp. 1-10, 2013.

[30] P. Sihombing and D. Rizal, "Pengaruh Indeks Saham Global dan Kondisi Makro Indonesia Terhadap Indeks Harga Saham Gabungan Bursa Efek," Media Ekon., vol. 22, no. 2, pp. 133-150, 2014.

[31] A. S. Santoso, "Analisis Hubungan Variabel Makroekonomi Terhadap Pasar Modal Indonesia dengan Pendekatan Error Correction Model (ECM) Periode September 2013 Juli," Universitas Muhammadiyah Surakarta, 2018.

[32] M. Mahdi and D. Kaluge, "Pengaruh Tingkat Suku Bunga (Birate) Dan Kurs Dolar As Terhadap Indeks Harga Saham Gabungan (Ihsg) Dengan Menggunakan Metode Error Corection Model (Ecm)," J. Ekon. Pembang., vol. 9, no. 2, p. 308, 2009.

[33] S. R. Ranto, "Pengaruh Jangka Pendek dan Jangka Panjang Variabel Makro Ekonomi Terhadap IHSG di Bursa Efek Indonesia Dengan Pendekatan Error Correction Model ( 
ECM)," vol. 6, no. 1, pp. 12-24, 2019.

[34] A. Normalita, "Analisis Hubungan Jangka Pendek dan Jangka Panjang Variable Makro dan Indeks Dow Jones Terhadap Pergerakan IHSG (Periode Oktober 2014-Agustus 2017)," Universitas Islam Indonesia, 2018.

[35] R. Maryatmo, "Pengaruh Jangka Pendek Dan Jangka Panjang Perubahan Suku Bunga Dan Kurs Rupiah Terhadap Harga Saham: Studi Empiris Di Indonesia ( 2000: 1 2010 : 4 ),” J. Ekon. dan Kebijak., vol. 3, no. 1, pp. 1-11, 2010. 